\title{
ADDENDUM \\ TO THE ANNUAL ENVIRONMENTAL MONITORING REPORT \\ OF THE LAWRENCE BERKELEY LABORATORY
}

1977

Dccasiunally during the year, a power failure will occur and produce a noticeable effect in the telemetered data from one or more of the Environmental Monitoring Stations. Such an event will cause the daily readings from the station to appear below the "normal background" for a period of time.

Two stations were effected this way during 1977. The 01ympus Gate Station was effected on 19 September 1977, and 22-28 November 1977, during the Thanksgiving Holiday period. The Building 90 Station had a telemetry loss during 23-26 September 1977. See Figs. 4 and 6.

There is no statisticaliy significant change in the reported values shown in Table 2 as a result of these events. 
LBL 7530

UC-41

T1D-4500- R66

\section{ANMUAL ENYIRONMENTAL HONITORING REPORT OF THE \\ LAHRENCE BERKELEY LABORATORY}

1977

Prepared by the Stzff of the

Engineering and Technical Services Division

Lawrence Berkeley Laboratory

March 1978

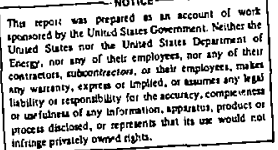

Editor: Lloyd D. Stepiens 
The following staff of the Environmental Health and Safety Department of the Engineering and Technical Services Division have contributed to the preparation of this report.

H. P. Cantelow

G. E. Schleimer

A. R. Smith

L. [ ephens

R. H. Thomas

J. Young 
TABLE OF CONTENTS

Abstract ..................... v

1. Environmental Monitoring Data-m1977 .......... . I

1.1. Accelerator Produced Radiation. . . . . . . . . 1

1.2. Radionuclide Measurements and Release ...... 12

1.2.1. Atmospheric Sampling. .......... 12

1.2.2. Water Sampling. . . . . . . . . . 16

1.3. Population Dose Equivalent for 1977 Results from

LBL Operation ................. 16

1.4. Non-Radioactive Pollutants. . . . . . . . . 21

2. Summary of Environmental Monitoring Data and Trends .... 21

2.1. Accelerator Produced Penetrating Radiation. . . . . $2 \mathrm{i}$

2.2. Release of Radionuclides. . . . . . . . . 21

References ........................... 28

Distribution List. ..................... 29 


\section{ABSTRACT}

The data obtained from the Environmental Monitoring Program of the Lawrence Berkeley Laboratory for the Calendar year 1977 are described and genera1 trends are discussed. 


\section{PREFACE}

In 1976 we published the Annuai Environmental Monitoring Report in two parts. Part One, LBL-4678, (1) discussed in detai $i$ the modeling used to determine the population dose equivalent due to Laboratory operations. This volume also described natural radiation background, geological features, climate and meterology, and the environmental surveillance progran of the Lawrence Berkeley Laboratory. Part Two, LBL-4827, (2) included the resuits of the sampling and measuring programs and the other necessary data to derive the environmental impact of Laboratory operations for 1975.

This year we wil] only reference $\mathrm{LBL}-4678$, thereby reducing the Annual Environmental Report to the essential details. 
1. Environmental Monitoring Data _- 1977

1.1. Accelerator-Produced Radiation

Figures 1 through 8 summarize the daity dose equivalent recorded for each environmental monitoring station due to photons and neutrons. These figures include natural background with the fluctuations due primarily to statistical variations.

There are some identifiable periods of accelerator operation that produced environmental radiation. These are listed in Table 1.

TABLE I.

\begin{tabular}{|c|c|c|c|}
\hline Inclusive Dates & Accelerator & Beam & $\begin{array}{c}\text { Environmentā } \\
\text { Monitoring } \\
\text { Station* }\end{array}$ \\
\hline $3 / 25-28 / 77$ & Bevatron & 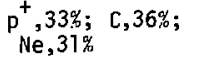 & OGEMS, 9OEMS \\
\hline $5 / 18-25 / 77$ & Bevatron & $\mathrm{p}^{+}, 27 \% ; \mathrm{C}, 73 \%$ & OGEMS, B8EMS \\
\hline $7 / 29-8 / 3 / 77$ & Bevatron & $\mathrm{p}^{+}$ & $\begin{array}{l}\text { OGEMS, 88EMS } \\
\text { 90EMS, PANEMS }\end{array}$ \\
\hline $1 / 7-14 / 77$ & B8-Inch Cyclotron & $120 \mathrm{MeV} \alpha$ & 88EMS \\
\hline $3 / 10-15 / 77$ & 88-Inch Cyciotron & $80 \mathrm{MeV}^{3} \mathrm{He}$ & 88EMS \\
\hline $5 / 28-6 / 2 / 77$ & 88-Inch Cyciotron & $90 \mathrm{MeV} \alpha$ & 88EMS \\
\hline $9 / 22-30 / 77$ & 88-Inch Cyclotron & $35 \mathrm{MeV} \mathrm{d}$ & 88EMS, 90EMS \\
\hline $12 / 7 / 77$ & 88-Inch Cyclotron & ${ }^{9} \mathrm{Be}^{4+}$ & $\begin{array}{l}\text { PANEMS, OGEMS } \\
\text { B8EMS, 90EMS } \\
\text { neutron and gamma }\end{array}$ \\
\hline $5 / 26-6 / 6 / 77$ & Supertilac & & OGEMS \\
\hline
\end{tabular}



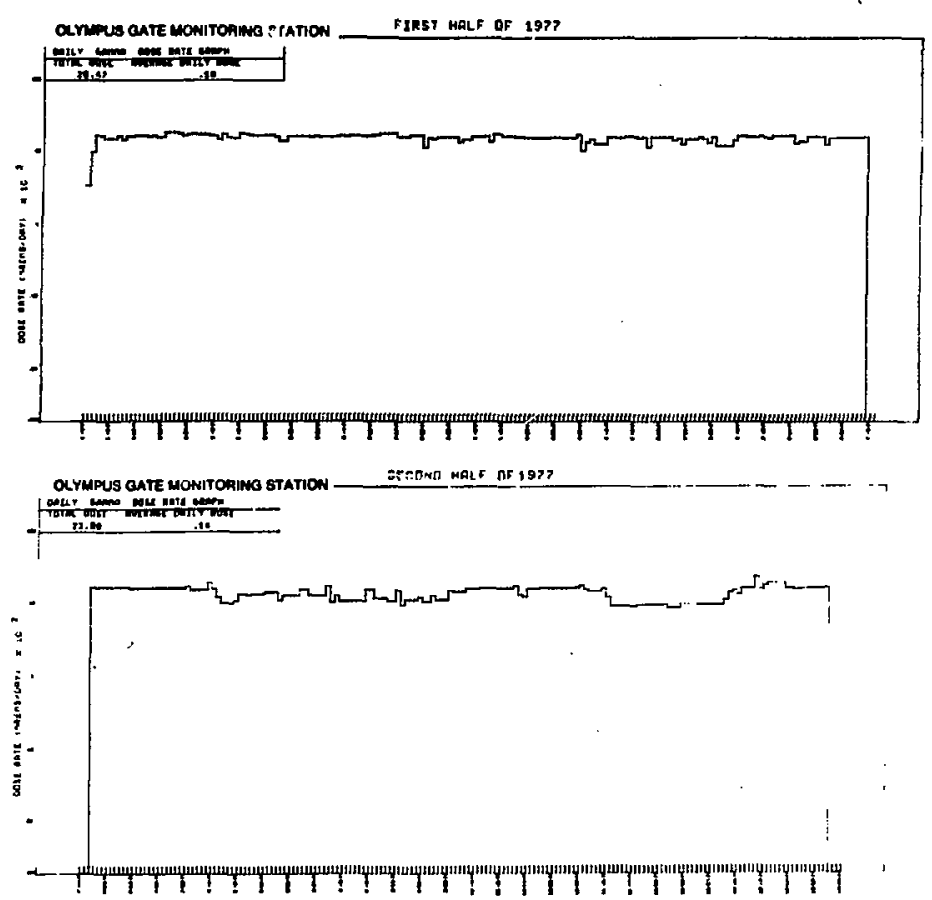

xd 703-7505

Fig. 1 

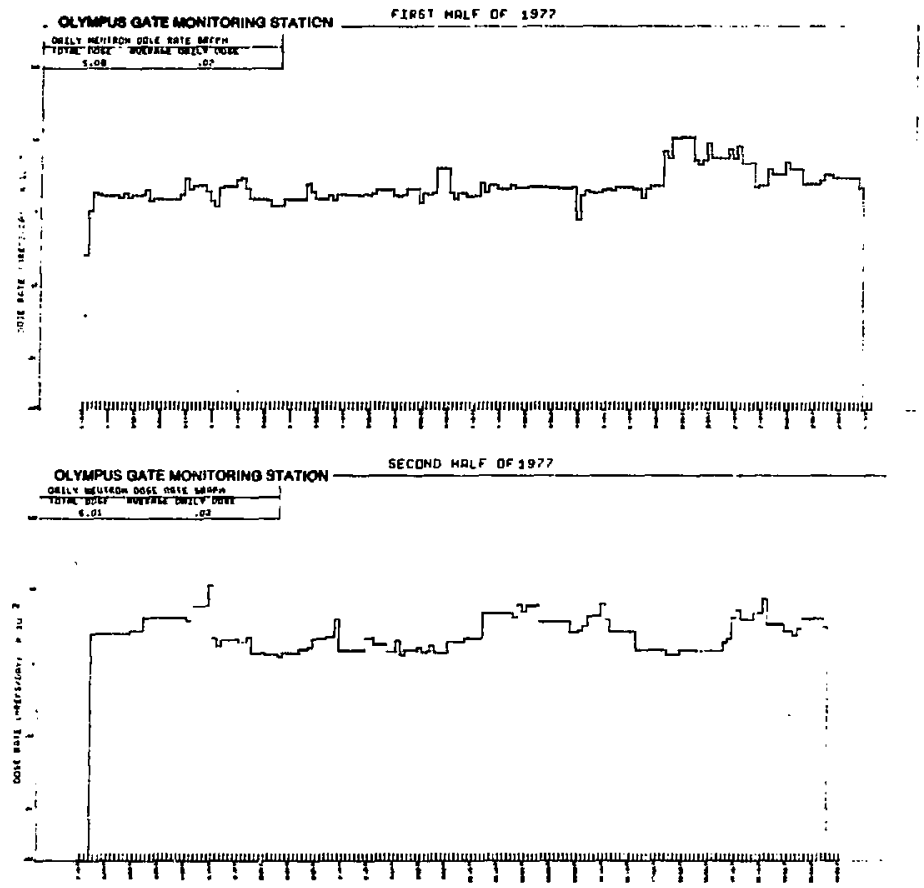

at 703756

Fig. 2 

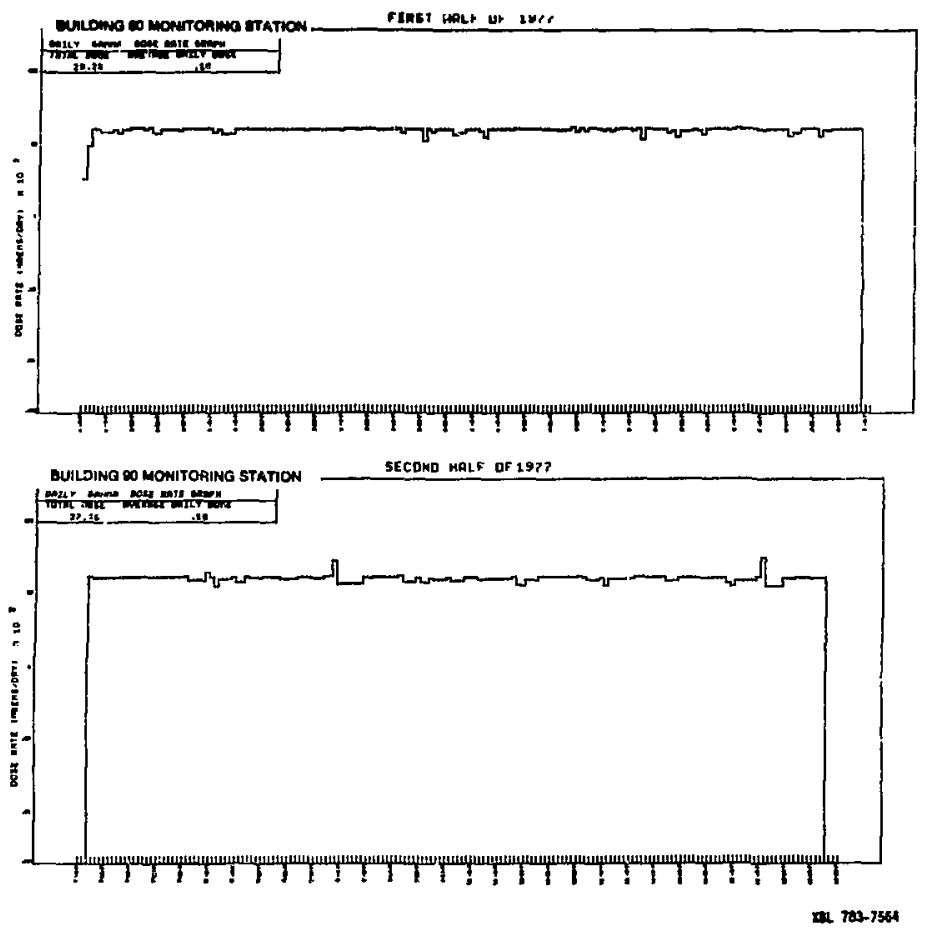

Fig. 3 
5

, WILAME D WONITOAING STATION ____ FIR5T HAL F DF $19 ? 7$

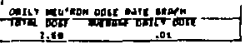
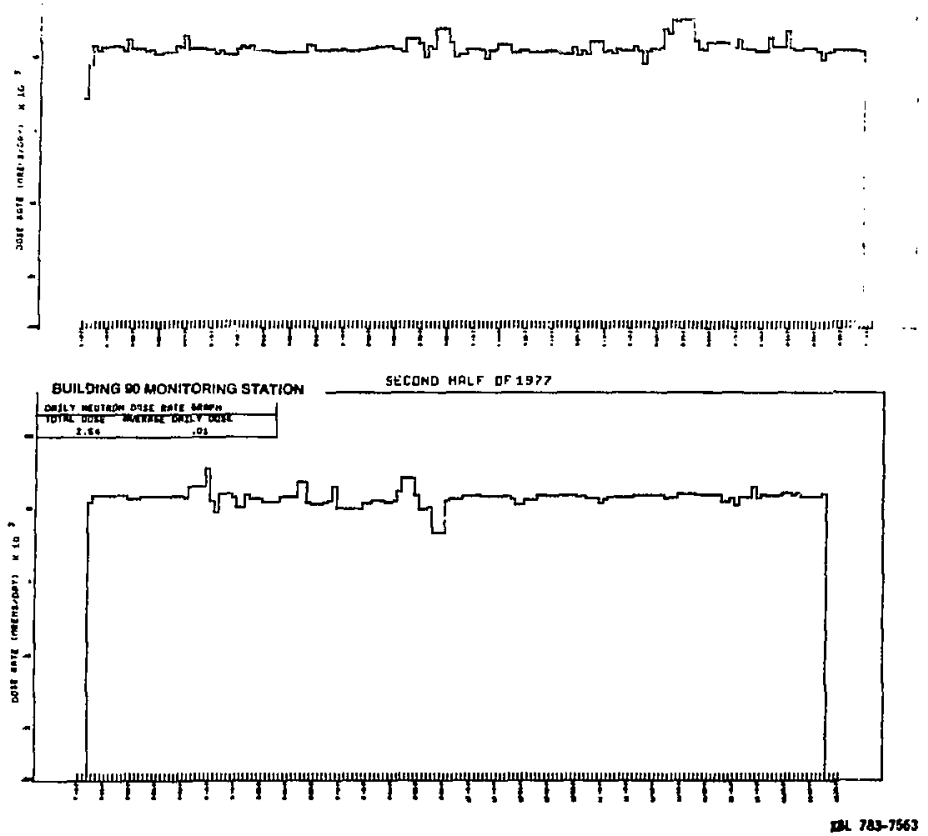

Fig. 4 
FIRST MALF OF 1977 Pill

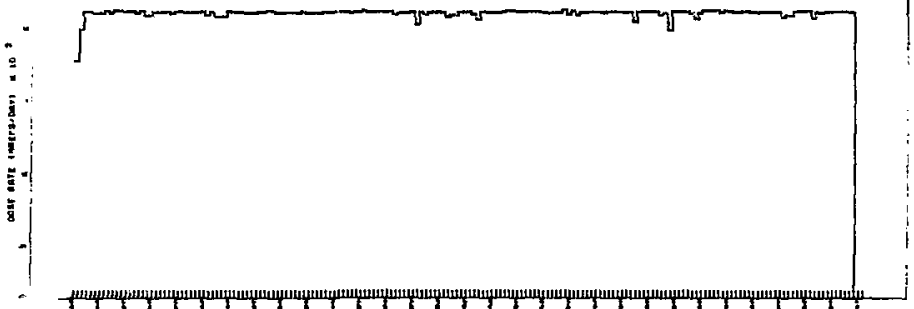

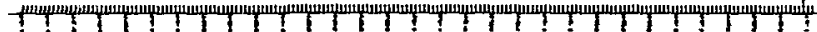

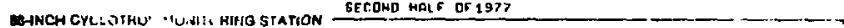

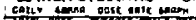

in

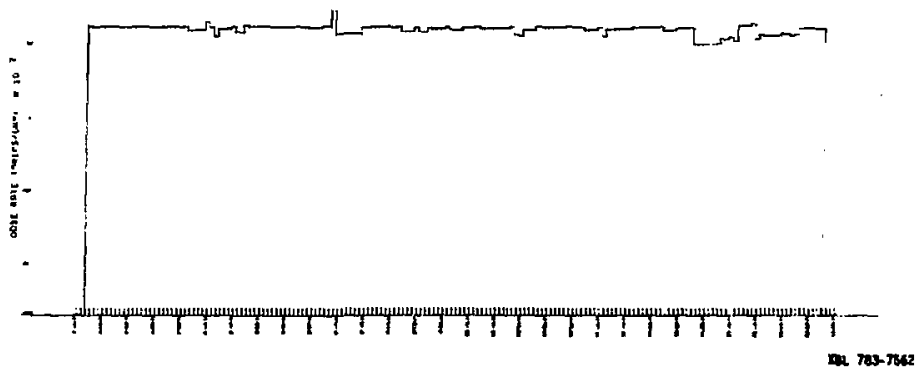

Fig. 5 

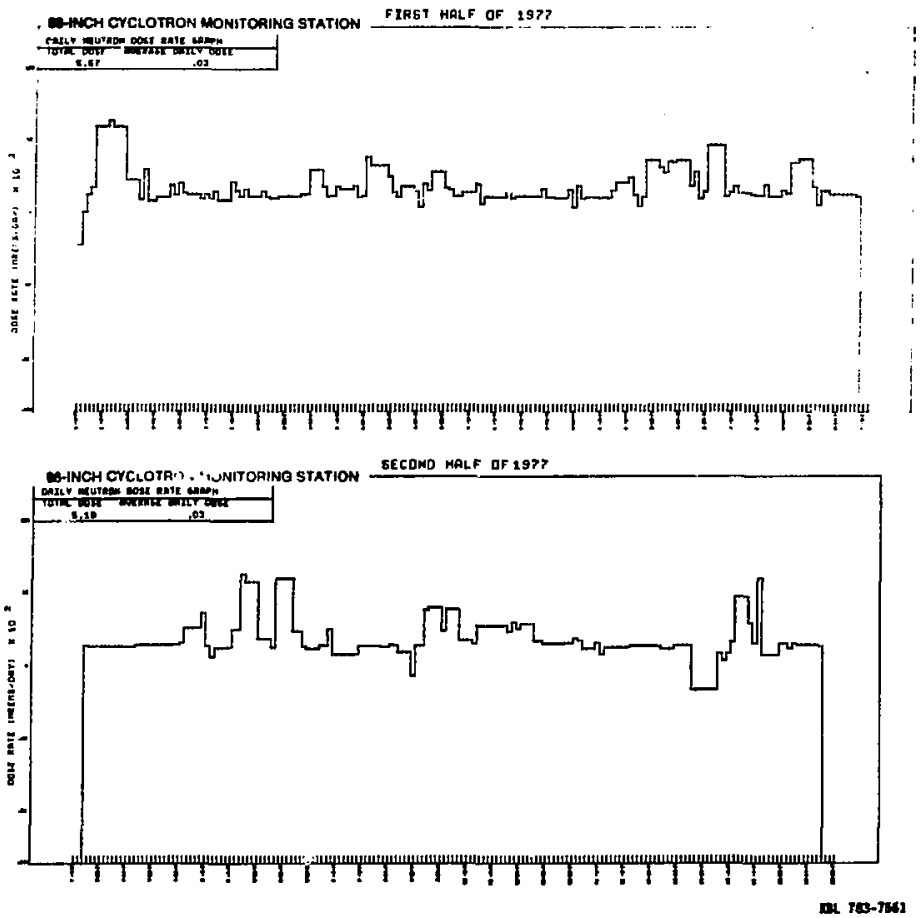

Fig. 6 

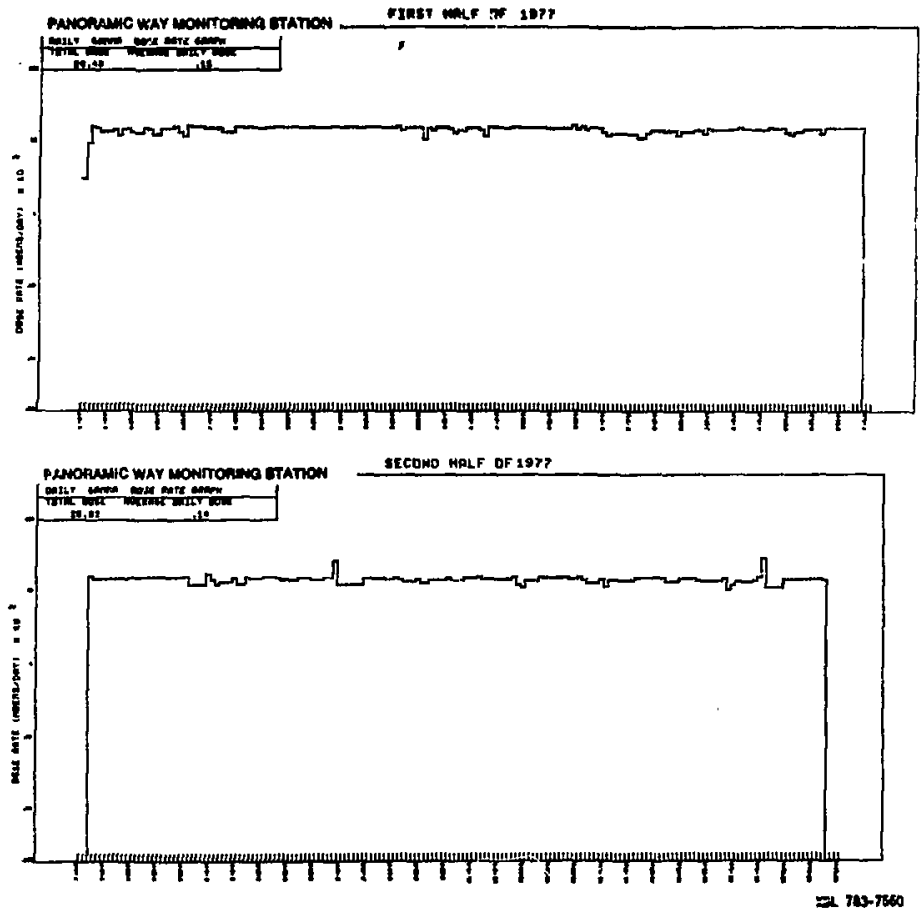

F1g. 7 


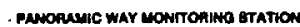

= IRST HALF OF 19??

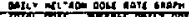

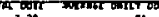
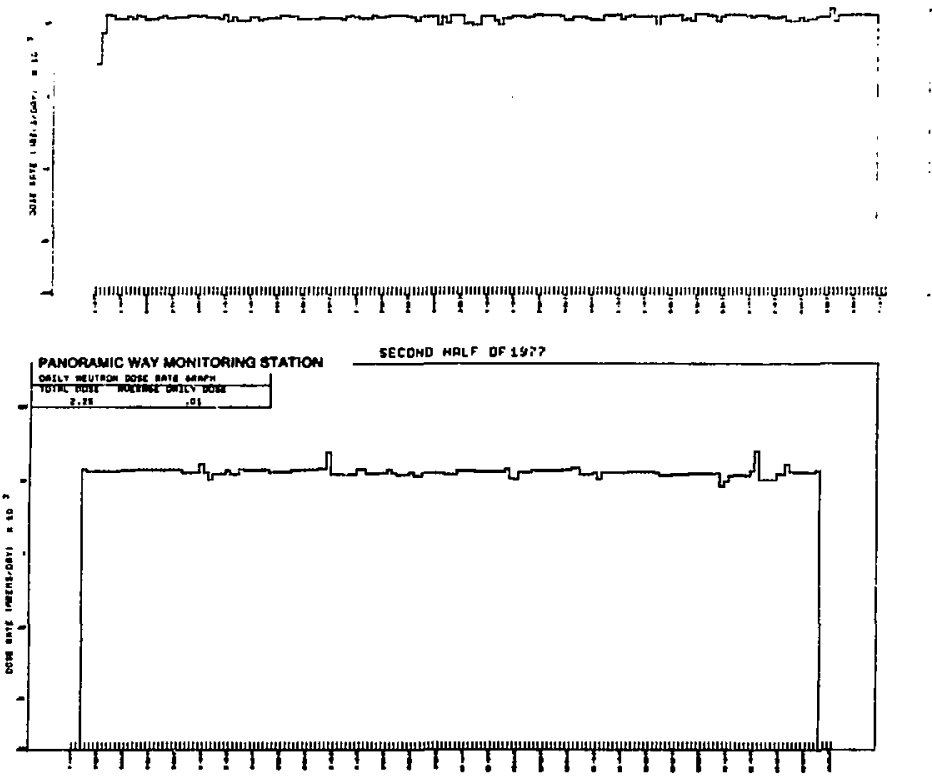

x) 7as-7ss

Ftg. 8 
Table 2 sumnarizes the total dose equivalent at each station during 1977. In evaluating the annual dose equivaient due to photons, the data summarized in Table 3 were used. In evaluating the annual dose equivalent due to neutrons, the neutron detector calibration factors and neutron backgrounds at each monitoring station are 1 isted in Table 4 . The net neutron count after background subtraction is converted to neutron fluence using the conversion factors of Table 4 . Because the neutron detectors do not respond over the entire energy spectrum, this measured fluence must be increased. Studies of the leakage neutron spectrum from accelerator shields at IEL show that the measured neutron fluence should be increased by a factor of 2.0 if the neutron spectrum at the environmental mionitoring station is similar to that around the Bevatron. Although this is probably a somewhat conservative assumption, it is at present adopted for our environmental radiation monitoring. The corrected fluence is converted to dose equivalent using a value of $1.86 \times 10^{-8} \mathrm{rem} \mathrm{n}^{-1} \operatorname{cin}^{2} .(5)$

\section{Table 2}

Radiation Levels at the LBL Site Boundary Due to Accelerator Operation--1977

\begin{tabular}{|c|c|c|c|}
\hline & $\begin{array}{l}\text { Total Dose } \\
\text { Equivalent from } \\
\text { Photons (millirem) }\end{array}$ & $\begin{array}{l}\text { Total Dose } \\
\text { Equivalent from } \\
\text { Neutrons (millirem) }\end{array}$ & $\begin{array}{l}\text { Total Dose } \\
\text { Equiva Tent } \\
\text { (mili irem) }\end{array}$ \\
\hline Location & $\begin{array}{l}\text { Jan. -Dec. } \\
\text { (Background } \\
\text { Subtracted) }\end{array}$ & $\begin{array}{l}\text { Jan.-Dec. } \\
\text { (Background } \\
\text { Subtracted) }\end{array}$ & $\begin{array}{l}\text { Jan.-Dec. } \\
\text { (Background } \\
\text { Subtracted) }\end{array}$ \\
\hline Olympus Gate & 0 & $4.5 \pm 0.01 *$ & $4.5 \pm 0.01^{*}$ \\
\hline 88-Inch Cyclotron & 0 & $5.3 \pm 0.01$ & $5.3 \pm 0.01$ \\
\hline Building 90 & 0 & 0 & 0 \\
\hline Panoramic Way & 0 & $0.9: \pm 0.01$ & $0.23 \pm 0.01$ \\
\hline \multicolumn{3}{|c|}{ Standard for Comparison $(4)$} & 500 milliren \\
\hline
\end{tabular}


Table 3

Data Used in Evaluation of Annual Dose Equivalent Due to Photons

\begin{tabular}{|c|c|c|}
\hline Location &  & $\begin{array}{l}\text { Calibration of } \\
\text { Detector } \\
\mu R / \text { Register Count }\end{array}$ \\
\hline 0lympus Gate & 76 & 1.24 \\
\hline 88-Inch Cyciotron & 105 & 1.13 \\
\hline Building 90 & 92 & 1.16 \\
\hline Panoramic Way & 112 & 1.11 \\
\hline
\end{tabular}

*Except neutrons.

The annual background reparted here ivas based on dry conditions of soil moisture and weather. 1977 was not an average year, due to the drought. There was one period during which gamma levels were detectable above background variations. This was during an 88-Inch Cyclotron beam development run on December 7, 1977.

\section{Table 4}

Neutron Detector Calibration Factors and Neutron Backgrounds at each Monitoring Station.

\begin{tabular}{lcc}
\hline Location & $\begin{array}{l}\text { Neutron Detector } \\
\text { CaTibration Factor } \\
\mathrm{n} \mathrm{cm} \text {-2/count }\end{array}$ & $\begin{array}{l}\text { Background } \\
\text { (Counts/Day) }\end{array}$ \\
\hline 0Tympus Gate & 16.3 & 26.9 \\
88-Inch Cyclotron & 15.6 & 27.5 \\
Building 90 & 13.1 & 37.3 \\
Panoramic Way & 13.5 & 24.7 \\
\hline
\end{tabular}




\subsection{Radiorıuclide Measurements and Release}

\subsubsection{Atmospheric Sampling}

The total quantities of radionuclides discharged into the atmosphere are summarized in Table 5. Although these amounts are greater than the amounts released in 1976 the quantities resulted in a small population cose equivalent (see Table 12).

Table 5.

Total Quantities Discharged into the Atmosphere--1977

\begin{tabular}{lc}
\hline Nuclides(s) & Quantity Discharged \\
\hline Alpha Emitters & $<1 \times 10^{-6} \mathrm{Ci}$ \\
$\begin{array}{l}\text { Unidentified Beta-Gamma } \\
\text { Emitters }\end{array}$ & $4.1 \times 10^{-5} \mathrm{Ci}$ \\
Carbon-14 & $2.5 \times 10^{-1} \mathrm{Ci}$ \\
Tritium & $78 \mathrm{Ci}$ \\
Gallium-67 & $1.3 \times 10^{-3} \mathrm{Ci}$ \\
Iodine-125 & $4.6 \times 10^{-4} \mathrm{Ci}$ \\
\hline
\end{tabular}

The general air sampling progran gave data all of which were within the range of normal background (Table 6). The special air sampling program for ${ }^{14} \mathrm{C}$ and ${ }^{3} \mathrm{H}$ found detectable concentrations of these nuclides (Table 7 ). Average concentrations of ${ }^{3} \mathrm{H}$ for the year were about equal to the radiation protection standards. The measurements of atmospheric deposition at perimeter stations all lie within the range of normal background, although small amounts of tritium were detected in rainfall collected within the Laboratory boundary. (Table 8) 
Table 6

Sumary of Air Samples--1977

\begin{tabular}{|c|c|c|c|c|c|c|c|c|c|}
\hline & \multirow[b]{3}{*}{$\begin{array}{l}\text { No. of } \\
\text { Samples }\end{array}$} & \multicolumn{6}{|c|}{ Concentration, $\left.10^{-15} \mathrm{\mu Ci} / \mathrm{m}\right]$} & \multicolumn{2}{|c|}{$\%$ of Standard } \\
\hline & & \multicolumn{3}{|c|}{ Alpha } & \multicolumn{3}{|c|}{ Beta-Gamma } & \multirow{2}{*}{$\begin{array}{l}\text { Alpha } \\
\text { Avg. }\end{array}$} & \multirow{2}{*}{$\frac{\text { Beta-Ganma }}{\text { Avg. }}$} \\
\hline & & Avg. & Min. & Max. & Avg. & Min. & Max. & & \\
\hline$\frac{\text { On-Site Average }}{\text { of To Locations }}$ & 504 & $0.35 \pm 0.10$ & $<2$ & 3 & $80 \pm 4$ & $<80$ & 520 & 2 & 0.8 \\
\hline \multicolumn{10}{|l|}{ Perimeter Stations } \\
\hline Building 88 & 51 & $0.91 \pm 0.33$ & $<2$ & 4 & $84 \pm 13$ & $<80$ & 430 & 5 & 0.8 \\
\hline Building 90 & 49 & $0.86 \pm 0.34$ & $<2$ & 3 & $88 \pm 13$ & $<80$ & 350 & 4 & 0.9 \\
\hline
\end{tabular}


Table 7

Summary of Special Air Sampling--1977

\begin{tabular}{|c|c|c|c|c|}
\hline & \multirow[b]{2}{*}{$\begin{array}{l}\text { No. of } \\
\text { Samples }\end{array}$} & \multicolumn{2}{|c|}{$\begin{array}{r}\text { Concentration } \\
10^{-9} \mu \mathrm{Ci} / \mathrm{ml}\end{array}$} & \multirow[b]{2}{*}{$\begin{array}{l}* \text { of } \\
\text { Standard }\end{array}$} \\
\hline & & Avg. & $\operatorname{Max}$. & \\
\hline \multicolumn{5}{|l|}{$\begin{array}{l}\text { Samples for } \\
\text { Tritium in Air }\end{array}$} \\
\hline$\frac{\text { On Site }}{\text { Bldg. } 3 \text { Roof }}$ & 51 & $2.0 \pm 0.2$ & $7 \pm 1$ & 1.0 \\
\hline$\frac{\text { Perimeter }}{\text { LHS }}$ & 50 & $1.8 \pm 0.2$ & $8 \pm 1$ & 0.9 \\
\hline $\begin{array}{l}\text { B13D } \\
\text { (01ympus) }\end{array}$ & 50 & $1.5 \pm 0.2$ & $8 \pm 1$ & 0.8 \\
\hline Standard for Comparison & \multicolumn{4}{|c|}{200} \\
\hline \multicolumn{5}{|l|}{$\begin{array}{l}\text { Samples for Carbon-14 } \\
\text { in Air (as } \mathrm{CO}_{2} \text { ) }\end{array}$} \\
\hline$\frac{\text { On Site }}{\text { Bldy. } 3 \text { Roci }}$ & 51 & $0.02 \pm 0.02$ & $.9 \pm .2$ & 0.02 \\
\hline Standard for Comparison & \multicolumn{4}{|c|}{100} \\
\hline
\end{tabular}


Table 8

Summary of Atmospheric Deposition--1977

\begin{tabular}{|c|c|c|c|c|c|c|c|c|}
\hline & \multicolumn{5}{|c|}{ Total Deposition, $10^{3} \mathrm{\mu Ci} / \mathrm{m}^{2}$} & \multicolumn{3}{|c|}{ Tritiun in Rainfall, $\mu_{C i} \mathrm{Cm}$} \\
\hline & $\begin{array}{l}\text { No. of } \\
\text { Samples }\end{array}$ & Avg. & $\operatorname{Max} . *$ & Avg. & B $\operatorname{Max}{ }^{*}$ & $\begin{array}{l}\text { No. of } \\
\text { Samples }\end{array}$ & Avg. & $\operatorname{Max}$. \\
\hline On site & & . & & & & & & \\
\hline (9. locations) & 108 & 0.00 & $0.02 \pm 0.04$ & 2.9 & $3.8 \pm 0.2$ & 81 & 2.5 & $20.8 \pm 1.0$ \\
\hline \multicolumn{9}{|l|}{ Perimeter } \\
\hline (4 locations) & 48 & 0.02 & $0.05 \pm 0.04$ & 4.5 & $9.0 \pm 0.2$ & 36 & 0.4 & $0.5 \pm 0.4$ \\
\hline
\end{tabular}

No standards for comparison have been established.

*Highest total for any one site. 


\subsubsection{Water Sampling}

Table 9 sumarizes the 1977 data from the surface water and tap water sampling program. These resuits are similar to those obtained in past years and all lie within the normal range of background activity. There is no reason to suspect that any of the observed radioactivity originated from the Laboratory as shown in the table.

One unusually high concentration of ${ }^{32} p$ was observed, but was very ? ikely due to a cross-contamination problem in the analytical laboratory.

\subsubsection{Sewer Sampling}

Table 10 sumarizes the sewage sampling data for 1977 . The sewer data are not significantiy different from the previous year's data. The campus of the University of California continued to discharge radioactive waste into the Strawberry sewer above the point at which it is monitored by LBL. LBL release practices have not changed during 1977 and are the same as in past years. The Hearst sewer concentration was less than $1 \%$ of the ERDA standard for discharge to sewers, however the Strawberry sewer was $14 \%$ of the standard ${ }^{(4)}$ (see Table 11).

1.3 Population Dose Equivalent Resulting from 1977 LBL Operation The population dose equivalent can be estimated as a function of the fence-post dose as a result of the various accelerator operating conditions and radionuclide releases. (5), (6) During 1977 the 88-Inch Cyclotron and SuperHILAC contributed a major portion of the measured radiation at the site boundary, $66 \%$. The Bevatron accounted for about $34 \%$ of the detectable radiation. 184-Inch operations were not significant during 1977. From Eq. $15{ }^{(5)}$ the corrected population dose equivalent, M, will be: 


$$
M=1000 H_{0}[1-0.56 f]
$$

where $\hat{f}$ is the fractioil of the time that the 88-Inch Cyclotron produced detectable radiation; $\mathrm{H}_{0}$, the measured fence-post dose equivalent substituting $f=0.66$,

$$
M=1000 \mathrm{H}_{\mathrm{g}}[0.63]
$$

The maximum dose equivalent at the site boundary due to penetrating radiation produced by accelerator operation was 5.3 millirem (Table 2, Section 1.1). The corresponding population dose equivalent is 3.3 man rem. The slight change from 1976 is due to statistical variations rather than changes in accelerator operation. The Bevatron proton runs produced some measurable radiation at the site boundary. The SuperHILA.C did produce some detectable radiation due to slightly higher beam currents. This is added to the 88-Inch Cyclotron contribution in our model.

The highest site boundary dose equivalent was detected at the monitoring station located only $\sim 100$ meters from the $88-$ Inch Cyclotron.

The population dose equivalent resulting from airborne releases of radioactive nuclides can be detemined from the model described in Ref. 6.

For the sake of providing more consistent reporting of these data, new values have been calculated for the constant "aR" (man-rem per curie released). The new values shown in Table 11 are based on MPC data listed in Chapter 0524 (Ref. 4). These values replace those lister in Ref. 1, Table 16. 
Table 9

Surface Water and Tap Water Samples--1977

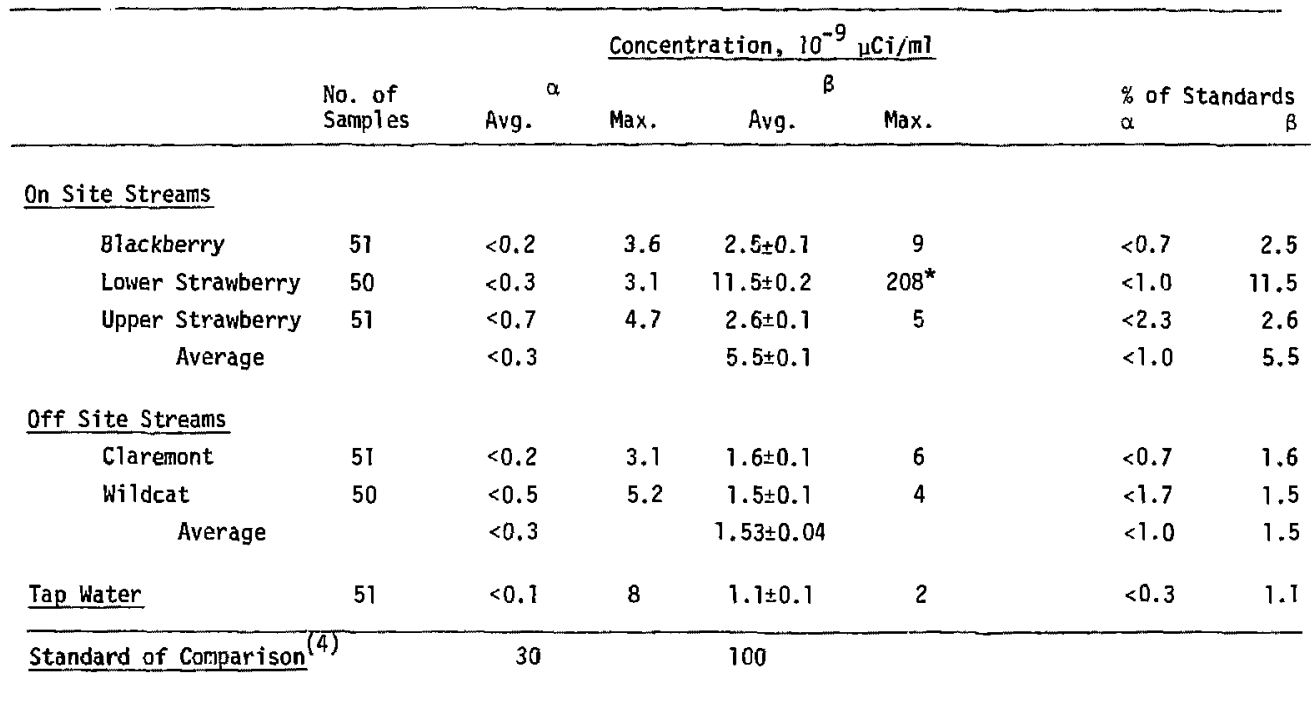

* Identified as ${ }^{32} p$. 
Tab?e 10

Surntrary of Sewage Sampling Data--1977

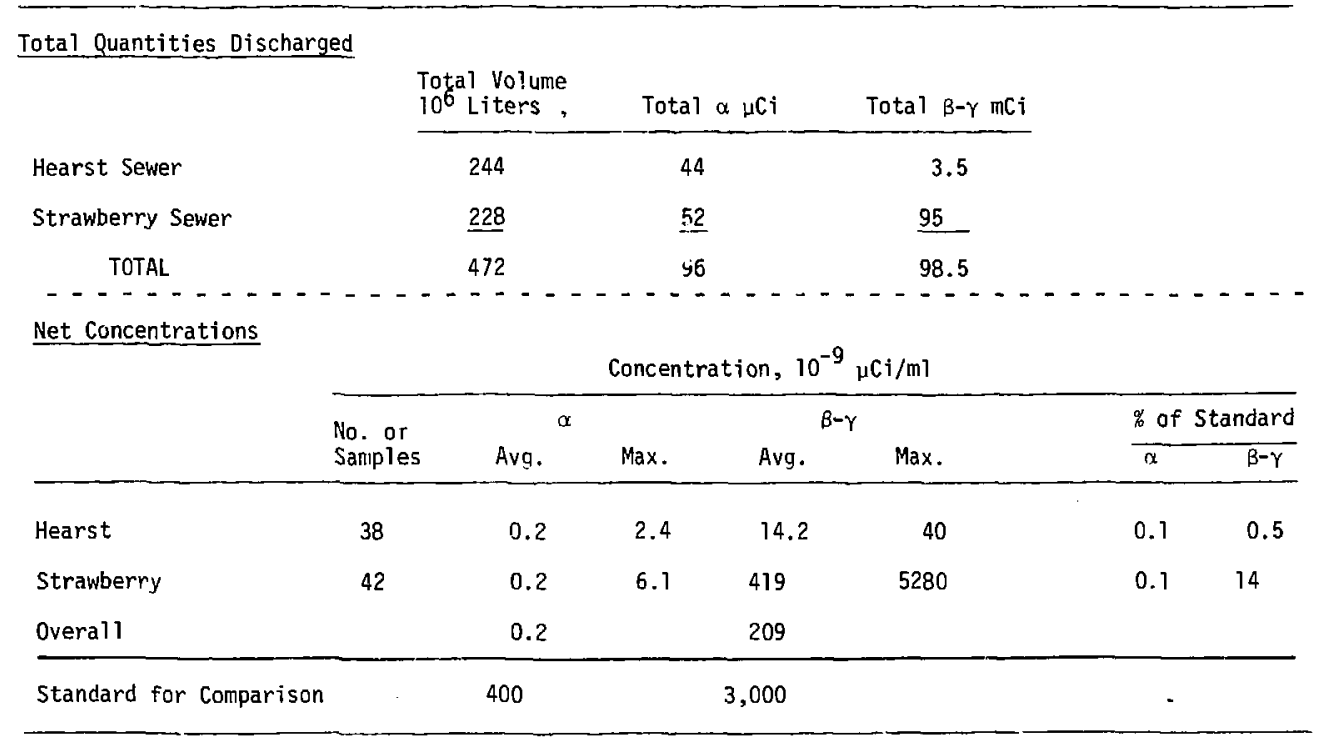


Table 11

Population Dose Equivalent Resulting from the Release of One Curie of Radionuclides

\begin{tabular}{|c|c|c|c|}
\hline Nuclide & $\begin{array}{c}M P C \\
(\mu \mathrm{Ci} / \mathrm{m} 1)\end{array}$ & $\left(\operatorname{Rem~}{ }^{3} \mathrm{Ci}^{\mathrm{R}} \mathrm{s}^{-1}\right)$ & $\begin{array}{c}\alpha \mathrm{R}^{(6)} \\
(\text { Man-rem/Ci) }\end{array}$ \\
\hline $\begin{array}{l}\text { Unidentified } \\
\text { alpha emitters }\end{array}$ & $2 \times 10^{-14}$ & $7.9 \times 10^{5}$ & $3 \times 10^{5}$ \\
\hline $\begin{array}{l}\text { Unidentified } \\
\text { beta emitters }\end{array}$ & $1 \times 10^{-11}$ & $1.6 \times 10^{3}$ & $7 \times 10^{2}$ \\
\hline $3_{H}$ & $2 \times 10^{-7}$ & .079 & .03 \\
\hline${ }^{34} \mathrm{C}$ & $1 \times 10^{-7}$ & .16 & .07 \\
\hline $125_{I}$ & $8 \times 10^{-11}$ & 200 & 80 \\
\hline${ }^{67} \mathrm{Ga}$ & $1 \times 10^{-10}$ & 160 & 70 \\
\hline
\end{tabular}

Table 12 summarizes the total population dose equivalent due to Laboretory operations.

$$
\text { Table } 12
$$

Population Dose Equivalerit--1977

\begin{tabular}{lc}
\hline & $\begin{array}{c}\text { Population Dose } \\
\text { (man rem) }\end{array}$ \\
\hline $\begin{array}{l}\text { Penetrating Radiation-- } \\
\text { Accelerator operation }\end{array}$ & 5.3 \\
Radionuclide Release & \\
${ }^{3} \mathrm{H}$ & 2.4 \\
${ }^{14} \mathrm{C}$ & 0.02 \\
${ }^{67}{ }_{\mathrm{Ga}}$ & 0.09 \\
${ }^{125} \mathrm{I}$ & 0.04 \\
Unknown B, $\gamma$ emitters & 0.03 \\
Unknown $\alpha$ emitters & $\leq 0.3$ \\
Tota] & $\mathbf{8 .}$ \\
\hline
\end{tabular}




\subsection{Non-Radioactive Pollutants}

The Laboratory does not carry out routine monitoring of airborne non-radioactive pollutants, however, sewer sampling is carried out for heavy metals. The analysis is achieved by atomic absorption.

Table 13 summarizes the sewer sampling data for heavy metals.

2. Summary of Environmental Monitoring Data and Trends

2.1 Accelerator-Produced Penetrating Radiation

The general trend of decreasing radiation levels at our site boundary due to accelerator operation during past years has leveled off during 1977 and in some areas shows a slight but not statistically significant increase as predicted in last year's summary. There were changes in both ion beams as well as current which have resulted in shifts in maxima at the monitoring stations.

The gamma levels are once again reported as zero. There is only one period of detectable gamma radiation due to accelerator operation.

Figures 9 through 12 show the annual dose equivalent reported from the environmental monitoring stations since they have been established.

Radiation levels at the 0lympus Gate Station have shown a steady decline since 1959 when estimates were first made. The 0lympus Gate Station is in direct view of the Bevatron and most directly influenced by that accelerator.

\subsection{Release of Radionuclides}

Over the past several years the atmospheric sampling program has, with the exception of occasional known releases, yielded data which are within the range of normal background. The surface water program iiwâys yields results within the range of normal background. As no substantial changes in the quantities of radionuclides used are anticipated, no changes are expected in these observations. 
Table 13

Summary of Sewer Sampling Data for Heavy Metals--1977

\begin{tabular}{|c|c|c|c|c|c|c|c|c|}
\hline & \multicolumn{2}{|c|}{ Metals Detected } & \multirow[b]{2}{*}{ Zinc } & \multirow[b]{2}{*}{ Silver } & \multirow[b]{2}{*}{ Cadmium } & \multirow[b]{2}{*}{ Nickel } & \multirow[b]{2}{*}{ Iron } & \multirow[b]{2}{*}{ Lead } \\
\hline & Chromium & Copper & & & & & & \\
\hline $\begin{array}{l}\text { Standard for Compari } \\
\text { EBMUD Limitation on } \\
\text { discharge (mg/l) }\end{array}$ & 2 & 5 & 5 & 1 & 1 & 5 & 100 & 2 \\
\hline \multicolumn{9}{|l|}{ Hearst Sewer } \\
\hline Average $(\mathrm{mg} / \mathrm{l})$ & 0.52 & 0.67 & 0.39 & $<0.04$ & $<0.02$ & $<0.05$ & 2.82 & $<0,06$ \\
\hline$\%$ of Standard & 26 & 13.4 & 7.8 & 4 & 2 & 1 & 2.8 & 3 \\
\hline \multicolumn{9}{|l|}{ Strawberry Sewer } \\
\hline Average $(\mathrm{mg} / \mathrm{l})$ & 1.12 & 4.5 & 2.98 & $<0.03$ & 0.05 & 0.77 & 15.08 & $<0,31$ \\
\hline$\%$ of Standard & 56 & 90 & 59.6 & 3 & 5 & 15.4 & 15 & 15.5 \\
\hline
\end{tabular}




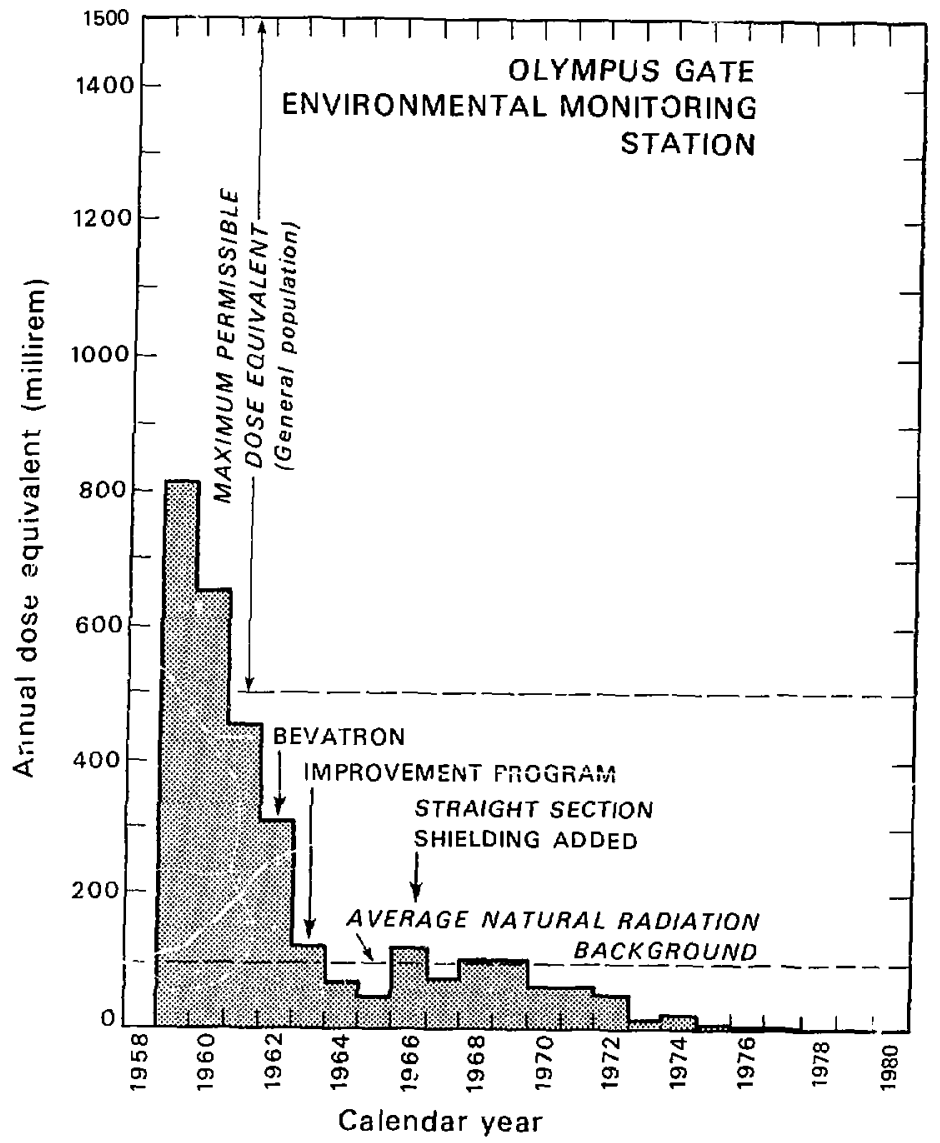

XBL 753-4766 B

Fig. 9 


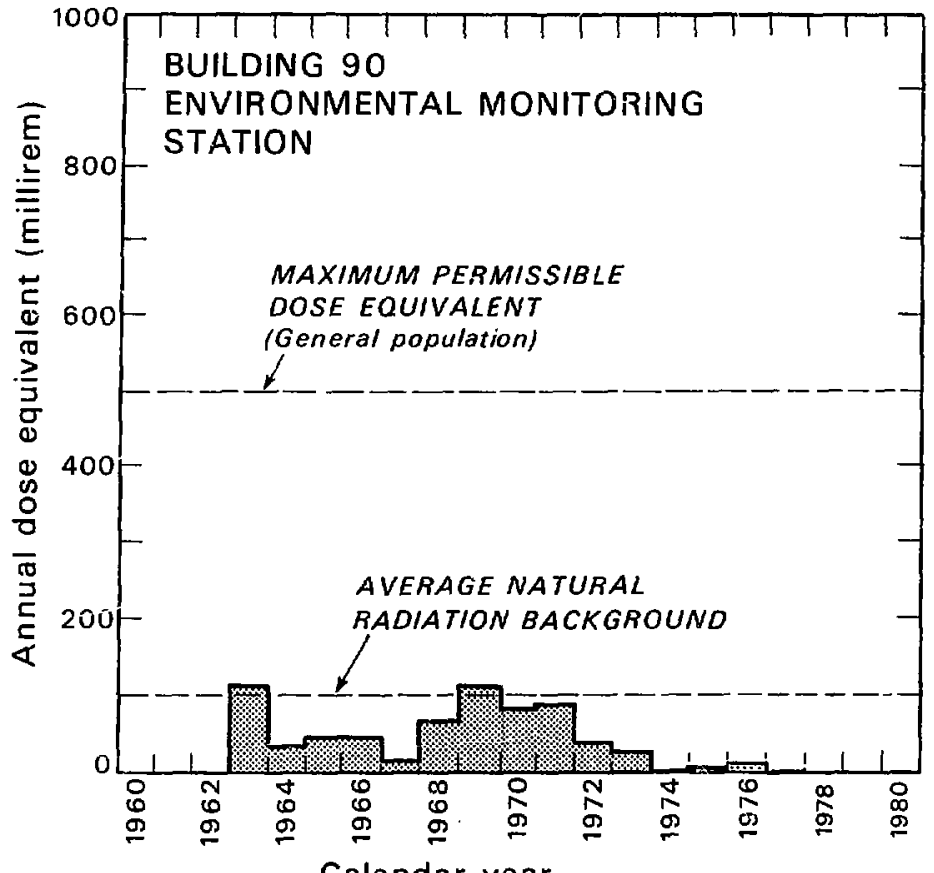

Calendar year

Fig. 10 


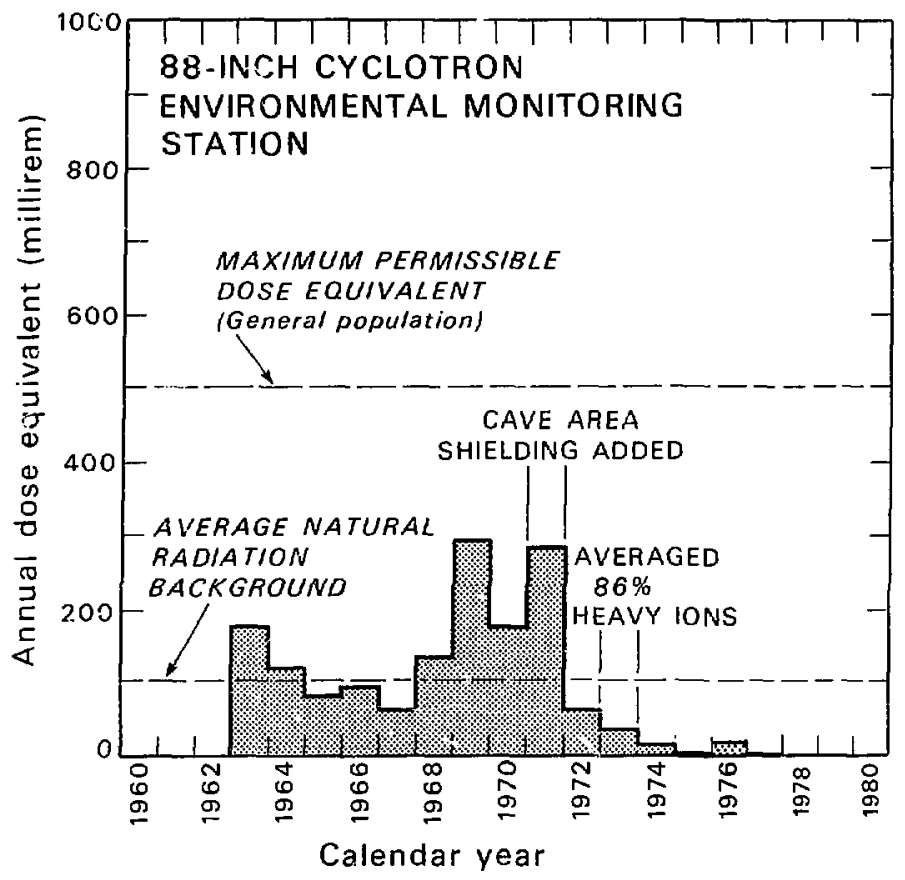

XBL 753.4767 B

Fig. 11 




XBL 353-4769 B

Fig. 12 
The practice of the University of California in discharging radionuclides in the Strawberry sewer continues to complicate the analysis of the sewer-sampling program data. Analysis also continues to be particularly difficult in view of the fact that the quantity of material discharged by the University is several times greater than that discharged by the Laboratory. Trends in sanitary sewer monitoring data are, therefore, unpredictable. 


\section{REFERENCES}

* This work was done with support from the U.S. Department of Energy

1. R. H. Thomas, Ed., The Environmental Surveillance Program of the Lawrence Berkeley Laboratory, Lawrence Berkeley Laboratory Internal Report, LBL-4678, Apri1 1976.

2. Staff Report, Engineering and Technical Services division, Lawrence Berkeley Laboratory, Annual Environmental Monitoring Report of the Lawrence Berkeley Laboratory 1975, LBL 4827.

3. W. S. Gilbert, et al., 1966, CERN-LRL-RHEL Shielding Experiment, Lawrence Radiation Laboratory Internal Report, UCRL-19794 (1968).

4. United States Energy Research and Development Adriinistration Manua 7, Chapter 0524-Standards for Radiation Protection.

5. Op Cit, Ref. 1 Section 4.2.3.

6. Op Cit, Ref. 1 Section 4.3.4. 